This PDF is a selection from an out-of-print volume from the National Bureau of Economic Research

Volume Title: Tax Policy and the Economy: Volume 4

Volume Author/Editor: Lawrence H. Summers, editor

Volume Publisher: The MIT Press

Volume ISBN: 0-262-19296-9

Volume URL: http://www.nber.org/books/summ90-1

Conference Date: November 14, 1989

Publication Date: January 1990

Chapter Title: Who Benefits from Capital Gains Tax Reductions?

Chapter Author: Daniel Feenberg, Lawrence H. Summers

Chapter URL: http://www.nber.org/chapters/c11570

Chapter pages in book: (p. 1 - 24) 


\section{WHO BENEFITS FROM CAPITAL GAINS TAX REDUCTIONS?}

\section{Daniel Feenberg NBER}

\section{Lawrence Summers}

Harvard University and NBER

\section{EXECUTIVE SUMMARY}

This paper examines the distribution of the benefits associated with reductions in capital gains taxes. Plans which reduce capital gains taxes by excluding a fixed fraction of capital gains from taxable income, by taxing real rather than nominal gains, and by using a sliding scale capital gains exclusion are considered. We reach three main conclusions.

1. Using plausible measures of economic status, capital gains receipts are highly concentrated among those with high incomes. The richest 2 percent of Americans receive more than 50 percent of all capital gains. Claims that capital gains recipients only appear to be rich because their capital gains income is transitory are not supported by longitudinal data. Likewise, claims that a large fraction of the benefits from capital gains tax reductions flow to middle income taxpayers result from failing to consider tax shelters. Capital gains on corporate stocks are considerably more concentrated among high income individuals than capital gains on other assets. 
2. There are important differences in the distributional consequences of different approaches to reducing capital gains taxes. Indexation yields greater benefits to lower income taxpayers than a general capital gains exclusion because they typically hold assets longer before selling them, and because they typically enjoy smaller gains than higher income taxpayers. Indexation also favors real estate over corporate stocks to a much greater extent than does a general exclusion. A sliding scale capital gains tax cut, based on the amount of time an asset is held has distributional consequences very similar to a general exclusion.

3. Most capital gains are realized on assets that were held for 10 or more years. Reductions in capital gains taxes would, for many years, benefit primarily assets that are already in place. Confining capital gains relief to future gains would substantially reduce the revenue cost of capital gains reform.

Proposals to reduce taxes on capital gains remain controversial. Disagreements stem from three sources. First, different observers with different values assess even agreed-on outcomes differently. Some regard increasing economic growth as of paramount importance, while others place more emphasis on distributional effects. Second, there are differences of opinion about the likely response of economic behavior to changes in capital gains tax rates. Proponents believe that capital gains cuts will have major effects on investment incentives and economic efficiency while opponents are skeptical of the importance of these effects and stress certain perverse incentives created by capital gains reductions. Third, there are different views about who will be the direct beneficiaries of capital gains cuts. Views differ about whether capital gains tax reductions primarily benefit high or middle income taxpayers, investors in new business or in tax shelters, and future investors or those who have invested in the past.

Disagreements over values are inherently unreconcilable. Disputes about the incentive and revenue effects of various tax reforms are potentially reconcilable, though considerable controversy remains. The question of who benefits from capital gains tax cuts is directly answerable with available longitudinal data on the returns of individual taxpayers. This paper uses these data to examine the distribution of the benefits from four different capital gains reform proposals: an across the board tax cut on long-term assets similar to the one proposed by the Bush administration; indexation of the basis on capital assets; a sliding scale capital gains tax rate that declines with the length of time for which an asset is held; and an alternative like the one considered by the Senate in 
the fall of 1989 that offered taxpayers a choice between indexing gains and length-of-time-based exclusion. We focus on three aspects of the distribution of the benefits from capital gains tax cuts.

First, will the benefits of capital gains tax cuts flow primarily to very wealthy taxpayers or will they be relatively evenly distributed? Income in a single year inclusive of capital gains may be a very poor indicator of a household's economic status. We therefore explore the distribution of capital gains tax liabilities by a variety of measures of economic well being, including average income over a four-year period, an estimate of taxable wealth, and for those who have not yet retired, wage and salary income. Regardless of what measure of economic status we use, we find that the majority of capital gains tax preferences go to those in the top 0.5 to 2 percent of the income distribution. Analyses suggesting otherwise are flawed by elementary errors such as using current wage and salary income to measure the economic position of those who have retired, or failing to take full account of preference income in assessing taxpayers' affluence.

While any reduction in capital gains tax burdens primarily benefits high income households, there are important differences in the distributional consequences of different plans. Because very high income taxpayers have typically earned larger capital gains, relative to the price at which they bought their assets, they gain less from indexing schemes which raise the basis on the sale of assets than do taxpayers who are less well off. For example, we estimate that 43 percent of an across the board exclusion for capital gains would go to the taxpayers with less than $\$ 100,000$ in AGI whereas 62 percent of the benefits of indexing capital gains would go to the same group. The distributional consequences of the pure sliding scale plan are quite similar to those of an across the board capital gains exclusion.

Second, which types of investment will benefit from capital gains tax reform? Many observers concerned with the competitiveness of American industry regard spurring investment in new equipment or technology as a higher priority than spurring investment in real estate or short-term financial instruments. Others are concerned with the distribution of benefits across different types of assets because they believe that the tax code already discriminates against certain classes of investment and believe that redress is appropriate. For the four capital gains reform proposals we consider, we estimate the fraction of relief going to different asset categories.

Our results suggest that, in general, less than half of the benefits of capital gains tax cuts go to owners of corporate stock. Only a small fraction of the benefits go to venture capital or small businesses. Nearly half of the reported capital gains involve real estate. There are some interesting 
differences between the effects of different capital gains cut reductions. For example, 27 percent of the benefit of inflation indexing goes to owners of corporate stock and 56 percent to owners of land and real estate. On the other hand, an across the board capital gains exclusion favors stockholders ( 42 percent of the benefit) at the expense of real estate investors ( 35 percent). The other plans we consider have intermediate effects.

Third, to what extent will capital gains tax cuts benefit capital that is already in place? For each of our four plans, we estimate the fraction of the benefits conferred in the five years following reform that will go to investments that had already been made at the time a plan was put into effect. We find that for each of the plans considered between 75 and 80 percent of first five years' tax relief will be a windfall to assets that are already in place. The windfall fraction is greater for the exclusion plans and less for indexing. lf, as proponents suggest, capital gains tax reductions would spur realizations, the fraction of windfall gains would be even higher. These results imply that very substantial reductions in the budgetary cost of capital gains tax reductions could be achieved by making them prospective.

The remainder of the paper is organized as follows. Section l considers the effects of capital gains tax cuts on the distribution of income. Section 11 examines their effects on different assets. Section 111 considers the distribution of benefits between past and future investments. Section IV examines how taking account of incentive effects might modify the conclusions of the earlier analysis and offers some concluding observations.

\section{CAPITAL GAINS TAX CUTS AND THE DISTRIBUTION OF INCOME}

This section examines the effects of capital gains tax reforms on taxpayers with differing incomes. As a number of analysts have pointed out, there are reasons for doubting that simple tabulations of who pays capital gains tax payments by income class say very much about the economic well-being of those who benefit from capital gains relief. First, when individuals sell assets on which they have large accrued gains, their single year income overstates the standard of living that they can sustain. Second, for taxpayers who successfully shelter income, adjusted gross income may understate true standards of living. The same is true of efforts to use wage and salary income to proxy economic wellbeing when retired people are included in the sample. In order to ad- 
TABLE 1

Distribution of Capital Gains Realization by AGI

\begin{tabular}{rccc}
\hline Percentile rank & AGI breakpoint & $\begin{array}{c}\text { Cumulative } \\
\text { percent } \\
\text { of AGI }\end{array}$ & $\begin{array}{c}\text { Cumulative } \\
\text { percent } \\
\text { of gains }\end{array}$ \\
\hline .5 & 203.0 & 8.0 & 54.0 \\
1.0 & 145.0 & 11.0 & 61.0 \\
2.0 & 106.0 & 15.0 & 68.0 \\
5.0 & 75.6 & 24.0 & 75.0 \\
10.0 & 59.0 & 35.0 & 80.0 \\
20.0 & 44.1 & 50.0 & 84.0 \\
50.0 & 20.8 & 85.0 & 91.0 \\
100.0 & & 100.0 & 100.0 \\
\hline
\end{tabular}

Source: 1986 Tax Model and authors' calculations. Dollar amounts in thousands of 1989 dollars.

* Schedule D and non-schedule D net gains before capital gains deduction. Losses limited to $\$ 3,000$.

dress these issues, we examine the distribution of realized capital gains by a number of different measures of economic status.

Table 1 presents the distribution of capital gains income by taxpayers' adjusted gross income. The data are drawn from NBER 1986 lndividual lncome Tax Model. They reveal that capital gains are much more concentrated than most other forms of income. Persons in the top 0.5 percent of the income distribution receive 54 percent of all capital gains compared with 8 percent of total income. lt appears that the top 2 percent of the population receives almost eight times as much capital gains income as the bottom 50 percent of the population. If adjusted gross income is accepted as a satisfactory measure of real affluence, it is hard to escape the conclusion that the proximate benefits of capital gains tax reductions are rich taxpayers.

It is often argued that statistics like those in Table 1 are very misleading because a sizable fraction of capital gains go to people of modest means who sell their home or their business and have their income artificially inflated for a single year. In order to examine this issue, Table 2 makes use of the most recently available panel data on individual tax returns. The data cover the period from 1979 to 1984 . Besides the differences in time period, the panel data are not comparable to the information in Table 1 because the panel sample contains relatively few high income taxpayers. ${ }^{1}$ Nonetheless, the panel information can be used to

${ }^{1}$ The standard tax file is a stratified random sample with weights attached to each return. The panel sample is a purely random sample of tax returns. 
TABLE 2

Distribution of Capital Gains Realizations by Average and Annual Income

\begin{tabular}{|c|c|c|c|c|}
\hline \multirow[b]{3}{*}{ Percentile rank } & \multirow{2}{*}{\multicolumn{2}{|c|}{$\frac{\text { Annual AGI }}{\text { With net capital gains }}$}} & \multirow{2}{*}{\multicolumn{2}{|c|}{$\begin{array}{c}\text { Average AGI } \\
\text { With net capital gains }\end{array}$}} \\
\hline & & & & \\
\hline & $\begin{array}{l}\text { Income } \\
\text { breakpoint }\end{array}$ & $\begin{array}{c}\text { Cumulative } \\
\text { net gain }\end{array}$ & $\begin{array}{l}\text { Income } \\
\text { breakpoint }\end{array}$ & $\begin{array}{l}\text { Cumulative } \\
\text { gains }\end{array}$ \\
\hline .5 & 217.0 & 42.2 & 211.0 & 36.1 \\
\hline 1.0 & 152.0 & 50.3 & 144.0 & 42.3 \\
\hline 2.0 & 115.0 & 56.5 & 110.0 & 49.4 \\
\hline 5.0 & 82.5 & 66.7 & 80.7 & 59.2 \\
\hline 10.0 & 65.7 & 72.4 & 63.8 & 65.9 \\
\hline 20.0 & 50.5 & 78.7 & 49.6 & 74.4 \\
\hline 50.0 & 37.5 & 89.1 & 26.6 & 87.7 \\
\hline 100.0 & & 100.0 & & 100.0 \\
\hline
\end{tabular}

- Source: 1979-1984 Panel File and authors' calculations. All dollar amounts in 1989 dollars. Sample is pooled 1979-1984 tax returns for taxpayers with four or more returns represented.

get an indication of the importance of the distortion caused by looking at only a single year's income.

The results in Table 2 on the distribution of capital gains income by total AGI inclusive of capital gains suggest that reliance on a single year's income in assessing the distributional impact of capital gains changes does not greatly distort the picture. For the panel sample, the data suggest that when income in a single year is studied, 50 percent of capital gains go to the top 1 percent of income recipients, whereas when average income is used, 43 percent of capital gains go the top 1 percent of income recipients. Similarly, using four-year average data reduces the share of capital gains going to the top 5 percent of capital gains recipients from 67 to 59 percent. To put these figures in perspective, note that the share of all income going to the top 1 percent of the population on an annual basis is 9 percent but falls to 8 percent on a four-year average basis. This suggests that capital gains income is not more transitory than most other components of income.

This inference is supported by the recent analysis of capital gains recipients by Slemrod et al. They report that half of the capital gains in the years 1981-1984 are realized by taxpayers with gains reported in each of the four years, and that only 6-13 percent of the gains (depending on the year selected) are reported by taxpayers realizing capital gains in only one of the four years. While they find that using average income over a several-year period considerably reduces the share of capital 
gains received by the $\$ 200,000$ and over income category, this is in a sense a statistical artifact. It occurs primanily because taking average income over a four-year period reduces the fraction of taxpayers in the $\$ 200,000$ and above category.

An alternative way of examining the distribution of the benefits from capital gains tax cuts, is to look at the distribution of capital gains by income categonies that exclude capital gains. Two approaches are suggested in this regard. Sometimes, the distribution of capital gains by income class exclusive of capital gains is examined. Alternatively, it is suggested that wage and salary income is a preferable proxy for true economic income. Both of these approaches are problematic since there is no reason why capital gains are not as much income as interest receipts or dividend payments. Furthermore, as we have just demonstrated, most capital gains do not represent transitory income. However, because statistics on the non-capital gains income of capital gains recipients are often used to support the claim that a substantial fraction of capital gains relief beneficiaries would be middle class, it is worth examining further the economic position of capital gains beneficiaries.

The first column of Table 3 reports the distribution of capital gains beneficiaries by non-capital gains income. When capital gains income is excluded, the distribution of capital gains appears to be much more egalitarian. The top 0.5 percent of recipients of non-capital gains income receive only 24 percent of all capital gains. Furthermore, the share of capital gains going to the half of the population with lower incomes rises to 11 percent when capital gains income is included in income, and to 30 percent when it is excluded. Statistics of this type have been used by the Wall Street Journal's editors and others to illustrate that the middle class is an important potential beneficiary of cuts in capital gains taxes.

Before accepting this conclusion, it is worthwhile to consider other characteristics of "low or moderate income" taxpayers who receive substantial capital gains income. Toward this end, the second column of Table 3 looks at the distribution of capital gains by income where income is expanded to include only positive items. This excludes tax shelter losses. It turns out to have a major impact on the distributional consequences of reductions in capital gains taxes. The share of capital gains received by the 0.5 percent of the population rises from 24 to 41 percent, and the share received by the lower half falls from 30 to 11 percent.

The striking differences between the tabulations which include and exclude loss items in measuring income suggest that there may be large differences between middle income families with and without capital gains receipts. Table 4 compares this group to other taxpayers with 


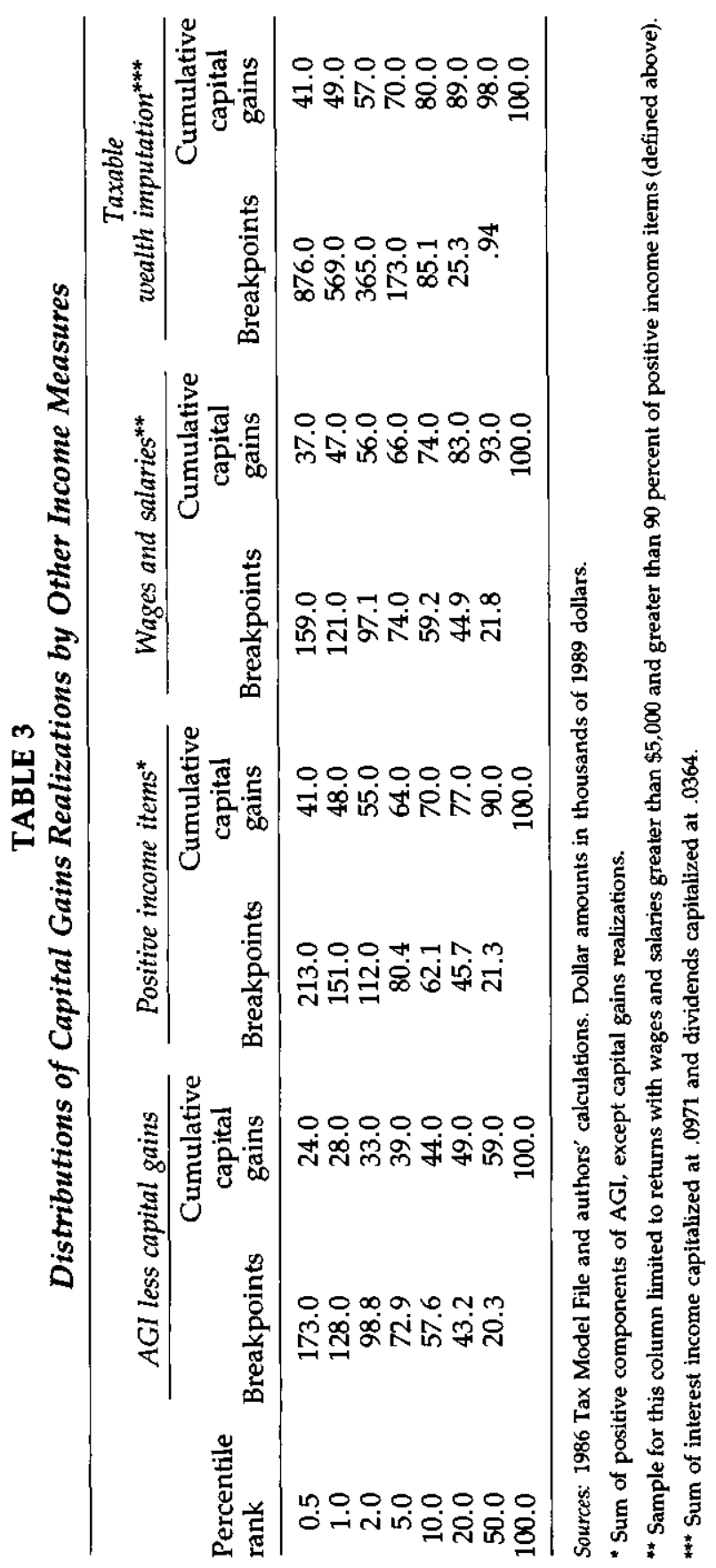


TABLE 4

Shelters and Capital Gains Income

\begin{tabular}{|c|c|c|}
\hline \multirow[b]{2}{*}{ AGI } & \multicolumn{2}{|c|}{ Weighted mean shelters* } \\
\hline & No capital gains & With capital gains \\
\hline 0 & 34,100 & 581,400 \\
\hline 12,000 & 311 & 27,400 \\
\hline 25,000 & 578 & 16,700 \\
\hline 50,000 & 942 & 14,700 \\
\hline 100,000 & 2,270 & 25,100 \\
\hline 200,000 & 11,500 & 28,900 \\
\hline 500,000 & 45,800 & 79,700 \\
\hline and up & 187,000 & 639,000 \\
\hline
\end{tabular}

Source: 1986 Tax Model File and authors' calculations. Dollar amounts in thousands of 1989 dollars. Potential negative items include Schedule C, Farm, Estate and Trust, Rent and Royalties. Small Business Corporations, Capital losses (Schedule D or 4797) and "other income." Sample restricted to returns with net gains.

* Equally weighted for returns with no capital gains. Other returns weighted by capital gains realized.

similar incomes but no capital gains. Clear differences emerge. Whereas the average taxpayer with an income between $\$ 12,000$ and $\$ 25,000$ reported only $\$ 578$ in losses, the average dollar of capital gains accruing to a person in this income class was associated with $\$ 16,700$ in reported losses. It turns out that fully 25 percent of capital gains are received by taxpayers whose non-capital gains income is negative. While it is difficult with the available information to pinpoint precisely the source of the tax losses that often coincide with capital gains income, it seems reasonable to suspect that tax shelter activity plays an important role.

Almost certainly, the true economic position of someone with a $\$ 75,000$ income after reporting a tax loss of $\$ 50,000$ is more favorable than someone with the same income and no negative tax items. Claims that a large fraction of capital gains are received by persons with moderate income should be accompanied by the further observation that most moderate-income recipients of capital gains had moderate incomes only because they were able to report tax losses.

These inferences are supported by a 1989 CBO staff memorandum that examined the distribution of capital gains income by a measure of expanded AGI. This measure includes items like tax-exempt interest and adds back an estimate of tax shelter losses. The CBO reports that 57.6 percent of gains went to the 0.5 percent of all taxpayers with income greater than $\$ 200,000$ in 1985 . Even when capital gains are entirely excluded from income, it appears that nearly 40 percent of capital gains go to taxpayers with among the top 0.5 percent of expanded income. 
The third column of Table 3 examines the distribution of capital gains by wage and salary income-another set of statistics that has been used to suggest that the middle class benefits substantially from cuts in capital gains taxes. Wage and salary income is misleading as an indicator of economic status because taxpayers who have retired and so no longer have wage and salary income appear poor even though they may in fact be quite wealthy. The same is true of the owners of small businesses. In order to address these issues, we include in our tabulation only taxpayers for whom wage and salary income represents more than 90 percent of non-capital gains positive income. The results indicate that once taxpayers who denive substantial income from sources other than wages and salaries and capital gains are excluded, the distribution of capital gains income again appears to be highly skewed toward the rich. Nearly 56 percent of capital gains go the highest-income 2 percent of taxpayers, who are primarily dependent on wages and salaries.

As an alternative approach to assessing the economic well-being of capital gains beneficiaries, the last column of Table 3 reports the distribution of capital gains by "taxable wealth." We estimate taxable wealth by grossing up dividends by the average yield on the stock market and interest payments by the average short-term interest rate. The results, in line with our other tabulations, suggest that more than half of capital gains go to the wealthiest 2 percent of the population.

The evidence in Tables 1-4 suggests that the standard tabulation of capital gains income by AGI overstates slightly the concentration of capital gains income in the upper end of the income distribution by failing to recognize that capital gains income is transitory. Of at least equal importance, the concentration of capital gains income is understated because many apparently moderate income capital gains recipients have probably reduced their reported income significantly by using tax shelters. There is no clear-cut direction of bias in simple tabulations of the distribution of capital gains by AGI. The conclusion that most capital gains go to very high income taxpayers is robust to plausible variations in the exact income concept used to assess the issue.

\section{Alternative Approaches to Reducing Capital Gains Taxes}

It appears that most capital gains go to those in the upper part of the distribution of true income. However, it is of some interest to examine whether or not different capital gains reduction plans have different distributional impacts. Differences might arise if, for example, the typical ratio of sale price to basis was different for taxpayers in different income categories, or if taxpayers in different income categones differed in how rapidly they turned their assets over. 
We consider four plans in our analysis. The first straight exclusion plan is similar to the one proposed by the president during the 1988 campaign. It would exclude 40 percent of all long-term (over one year) capital gains from income, regardless of how long an asset had been held. The second, an indexing plan, would tax only the real component of capital gains. In order to measure the real component of gains, the purchase price of an asset is stepped up by the increase in the general price level since it was purchased before calculating the gain. Most indexation proposals and the one considered here does not allow indexing to create capital losses. The third, a sliding scale plan, calls for an exclusion which increases as the length of time an asset has been held rises. The plan considered here is an exclusion that increases at 5 percent a year for seven years and then reaches a maximum of 35 percent on assets sold after seven or more years. The fourth, a combination plan, allows taxpayers to compute their tax liability on the basis of either the indexing or the sliding scale plan and use whichever plan is more favorable.

In order to examine these plans, it is necessary to have data on the purchase date, purchase price, and sale price of individual assets along with individual returns. Without this information, it is not possible to simulate the effects of indexing or introducing a sliding scale based on holding periods. Such data exist for 1973, 1981, and 1985, having been collected by the Treasury at a cost that exceeds $\$ 1$ million for each survey. Unfortunately, the Treasury has been and remains unwilling to release the 1981 and 1985 information to outside researchers. As a consequence, we have to work with 1973 information.

This creates a variety of problems. Most obviously, there is the likelihood that patterns of capital gains realization have changed over time. There is also the fact that the inflation history has certainly changed since 1973. Since inflation rates were much lower prior to 1973 than they have been over the last 15 years, there is no reason to suppose that the fraction of gains that represents real income has remained constant. In order to address this issue, we have put the data on a contemporary basis using the following procedure.

We made a strict application of Fisher's law to adjust the basis of each asset sold in 1973. That is, we assumed that inflation adjusts the nominal, but not the real, return on assets. This assumption is questionable in the presence of taxes but provides a concrete basis for analysis. The imputation inflates the sale price of assets sold in 1973 to 1992 dollars (5 percent inflation is assumed for 1989-1992), but adjusts the basis to maintain the same real rate of return over the holding period ending in 1992 as was actually earned for the holding period ending in 1973. The effect of this procedure is to keep the distribution of real capital gains 
income constant but to alter the magnitude of reported nominal gains on individual tax returns.

Table 5 reports the distributional consequences of the different plans. The results suggest a clear difference between indexation and other means of reducing capital gains taxes. The distribution of the benefits from each of the plans is highly skewed toward high income taxpayers. In the case of a straight exclusion of capital gains, 57 percent of the benefits would go to the 2.5 percent of taxpayers with incomes over $\$ 100,000$. Relative to other plans, the distribution of the benefits from indexation is highly progressive. While taxpayers with AGI less than $\$ 75,000$ (in 1990 dollars) would get 52 percent of the benefits from indexing, taxpayers in the same range would get only 34 percent of the benefits of a straight exclusion. The distributional consequences of the combination plan appear to be more like those of indexing than those of moving to a sliding scale. This is because the indexing option is more generous than the partial exclusion option for most taxpayers.

Table 6 illustrates the reason why indexation is more progressive than the other reforms considered. It reveals that the average ratio of sale price to purchase price is 65 percent for taxpayers with incomes under $\$ 75,000$, but 54 percent for taxpayers with incomes over $\$ 75,000$. This is in spite of the fact that holding periods were slightly greater ( 5.7 years vs. 4.8 years) for lower income taxpayers. Both the fact that basis starts out higher for lower income taxpayers, and their slightly longer holding periods operate to make indexation disproportionately advantageous for them. These results are consistent with the finding of Feldstein and Yitzhaki (1984) that high income taxpayers tend to earn higher returns on their investments than low income taxpayers although some kind of sampling bias might be an alternative explanation.

In assessing the result that indexation is more progressive than other methods of reducing capital gains tax burdens, it is important to recall that even its benefits are quite regressively distributed. More than half of the benefits would go to the taxpayers with incomes over $\$ 100,000$.

\section{Market Responses to Reforms}

In keeping with most previous investigations of the issue, the incidence calculations presented here take no account of tax induced changes in behavior and in market conditions that might follow capital gains tax reforms. This is unavoidable given the available data, but it raises a number of questions about how the conclusion reached here that capital gains tax cuts would be regressive would be modified if behavioral effects were recognized.

First, to the extent that capital gains tax cuts led to increased capital 


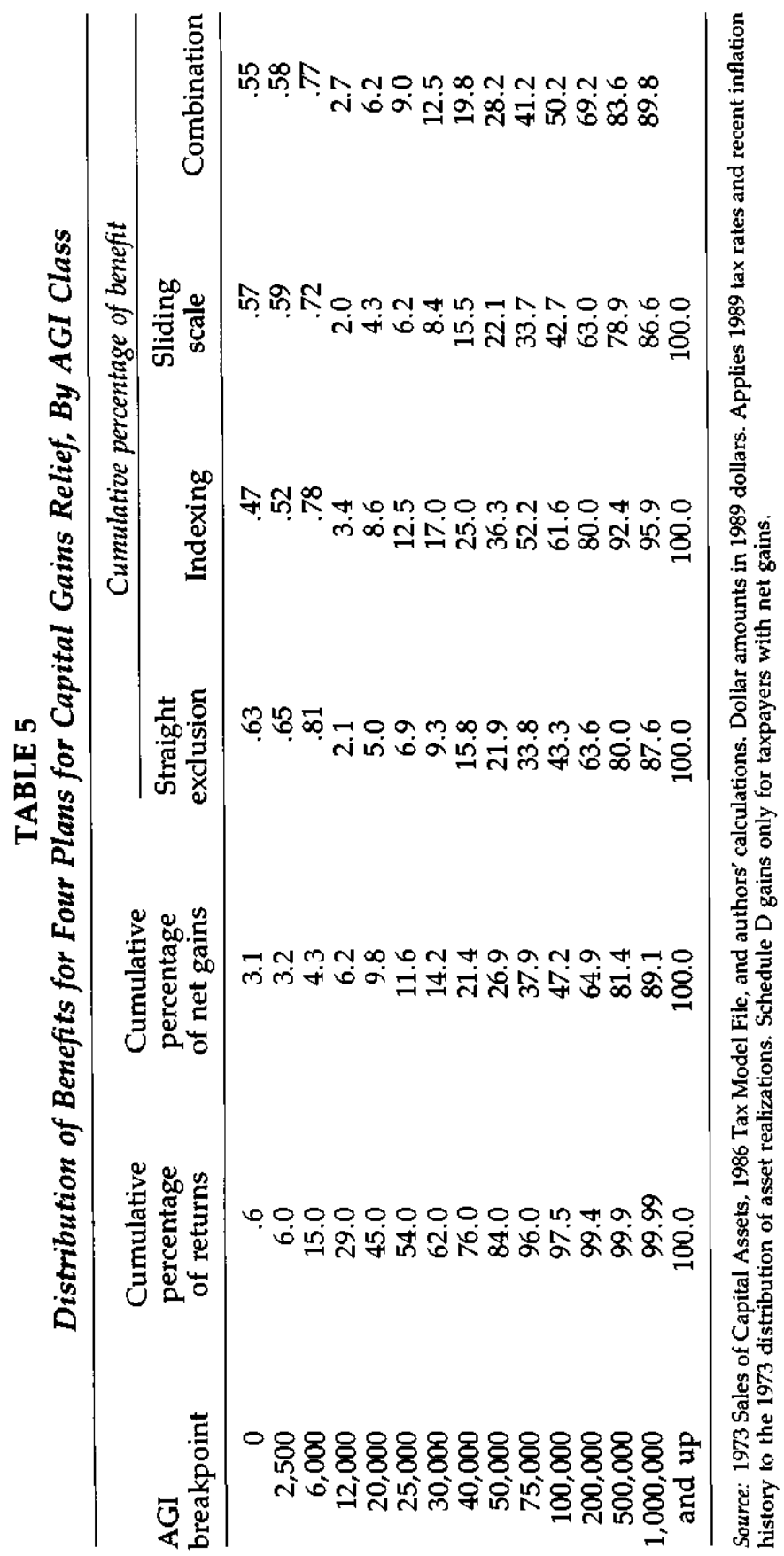


TABLE 6

Average Basis to Sale Price and Holding Period For Taxpayers in Different Income Classes

\begin{tabular}{lcc}
\hline AGl & $\begin{array}{c}\text { Basis/ } \\
\text { Sale ratio }\end{array}$ & $\begin{array}{c}\text { Holding } \\
\text { period }\end{array}$ \\
\hline $\begin{array}{l}\text { Less than } \$ 75,000 \\
\$ 75,000 \text { or more }\end{array}$ & .65 & 5.7 years \\
\hline
\end{tabular}

Source: 1973 Sales of Capital Assets and authors' calculations. Presumes recent inflation experience (see text). Capital loss returns excluded. Schedule D sales only.

gains tax realizations, reductions in tax revenues caused by lower rates would be at least partially offset by the greater volume of realizations. This argument is relevant for the purpose of estimating the government revenue consequences of capital gains cuts, but not for addressing their distributional consequences. By assuming no behavioral changes, the calculations above understate the true gain to capital gains recipients associated with capital gains tax cuts. Taking account of changes in behavior would only increase the apparent advantage conferred on capital gains recipients.

Second, it is possible that capital gains cuts would lead to increases in asset values. These changes are relevant to a full assessment of the distributional consequences of capital gains tax changes. In all likelihood they are highly tilted to the upper part of the income distribution. A Federal Reserve Study (1986) has estimated that the families in the top 0.5 percent of the income distribution own 43 percent of all stock, and that families in the top 10 percent of the income distribution own 85 percent of all stock.

The evidence in this section suggests that the benefits of reductions in capital gains taxes would flow primarily to persons with high standards of living. This conclusion does not depend on just how capital gains tax relief is provided, or on what measure of income is used in the analysis as long as elementary errors are avoided. Of course, the income distribution implications of capital gains tax cuts are only one relevant aspect. In the next section, we ask what types of investment would benefit most from capital gains tax reductions.

\section{WHICH TYPES OF INVESTMENT BENEFIT FROM CAPITAL GAINS TAX REDUCTIONS?}

This section examines the effects of capital gains tax reductions on the holders of different types of assets. This is relevant to an assessment of 
TABLE 7

Distribution of Benefits by Asset Type

\begin{tabular}{lcccc}
\hline & Indexing & $\begin{array}{c}\text { Straight } \\
\text { exclusion }\end{array}$ & $\begin{array}{c}\text { Sliding } \\
\text { scale }\end{array}$ & Combination \\
\hline Real Estate & 55.7 & 38.9 & 41.2 & 47.8 \\
Stocks & 27.3 & 42.0 & 39.9 & 33.7 \\
Timber & .6 & .7 & .8 & .7 \\
Other & 16.4 & 18.4 & 18.1 & 17.8 \\
\hline
\end{tabular}

Source: 1973 Sales of Capital Assets, 1986 Tax Model and authors' calculatlons. Applies 1989 tax rates and recent inflation experience to the 1973 distribution of asset realizations. Schedule D gains only, and only for taxpayers with net gains.

the desirability of capital gains tax cuts for at least two reasons. First, it may be that there is a stronger case for spurring some types of investment than others. It is often argued, for example, that corporate investments, particularly in new plant and equipment yield external benefits to other firms. Some observers argue that offering assistance to industries engaged in international competition should be an especially high priority. Second, it is often alleged that certain types of investment (e.g., real estate) are already heavily tax-favored because they can more easily hold tax-favored debt. See, for example, Gordon Hines and Summers (1987) and Summers (1987) for a discussion of these issues. Reductions in capital gains taxes on assets that are financed by issuing debt may be seen as less desirable than reductions in taxes on other assets. Japan and a number of other nations tax capital gains on corporate stocks at a lower rate than capital gains on real estate and other assets. (See Shoven, 1989.)

Table 7 presents evidence on the fraction of the benefits of each of four capital gains reductions plans that would flow to the holders of corporate stocks, real estate investors, timber investors, and other assets. Regardless of which plan is considered, a minority of the benefits go to the holders of corporate stock. It is striking that, despite the attention it receives in discussions of the capital gains issue only a very small fraction of capital gains benefits go to timber. ${ }^{2}$ Poterba (1989), who also considers the distribution of capital gains benefits across assets, finds notes that the share of the benefits which go to venture capital is very small. Most of the benefits go to real estate investments of various kinds and to assets that fall in the "other" category. This category includes

${ }^{2}$ This conclusion may be misleading because we are only examining capltal gains that appear on individual Schedule $D$ returns. This excludes depreciable business property and owner-occupied housing. 
collectibles, oil and gas, and bonds, among others. Probably some capital gains from the sale of small unincorporated businesses also show up in the "other" category.

Alternative capital gains reduction plans differ considerably in their impact on different assets. While real estate investment would gain twice as much from indexing as stock market investments, stocks would actually gain more from a straight exclusion than would real estate investments. The sliding scale plan is like the straight exclusion plan but is slightly more favorable to real estate. The differences here reflect the fact that real estate investments are typically held somewhat longer than other investments and the fact that capital gains on real estate sales are typically somewhat smaller than capital gains on sales of stocks. There is considerable evidence (for example, see Summers, 1981), that increases in inflation raise real estate prices relative to stock prices. To the extent that this is the case, the conclusion reached here would be reinforced.

The finding that indexing disproportionately benefits real estate investment raises questions about the extent to which it increases neutrality, since real estate investments are more highly leveraged than other forms of investment. lncreases in inflation, assuming the validity of the Fisher's law assumption maintained here, raise nominal interest rates and the value of nominal interest deductions. Because interest deductions, unlike capital gains are not deferred, the extra interest deductions on real estate investments may well exceed the increased capital gains taxes. In this case, indexing only capital gains would reduce rather than increase tax neutrality. There is also the further point that, as Gordon, Hines, and Summers (1987) document, inflation encourages tax arbitrage between high income landlords and low income tenants.

Both the Japanese example, and the differing degrees of leverage on corporate and non-corporate assets raise the possibility of changing the capital gains tax rules for some but not all assets. The original capital gains tax reform plan proposed by the Administration in 1989 would have reduced capital gains on corporate stocks but not on real estate investments. Similar plans have also been discussed in the Senate. Table 8 presents some information on the distributional consequences of reforms targeted at corporate stocks and at non-stock assets.

Two primary conclusions emerge. First, reductions in capital gains tax burdens on corporate stocks are more tilted toward those with high incomes than reductions in capital gains on non-stock assets. While nearly half of the benefits of a straight capital gains exclusion on nonstock assets would go to persons with incomes less than $\$ 100,000$, only slightly more than one-fourth of the benefits of excluding capital gains on corporate stock would go to persons in the less-than- $\$ 100,000$ income 


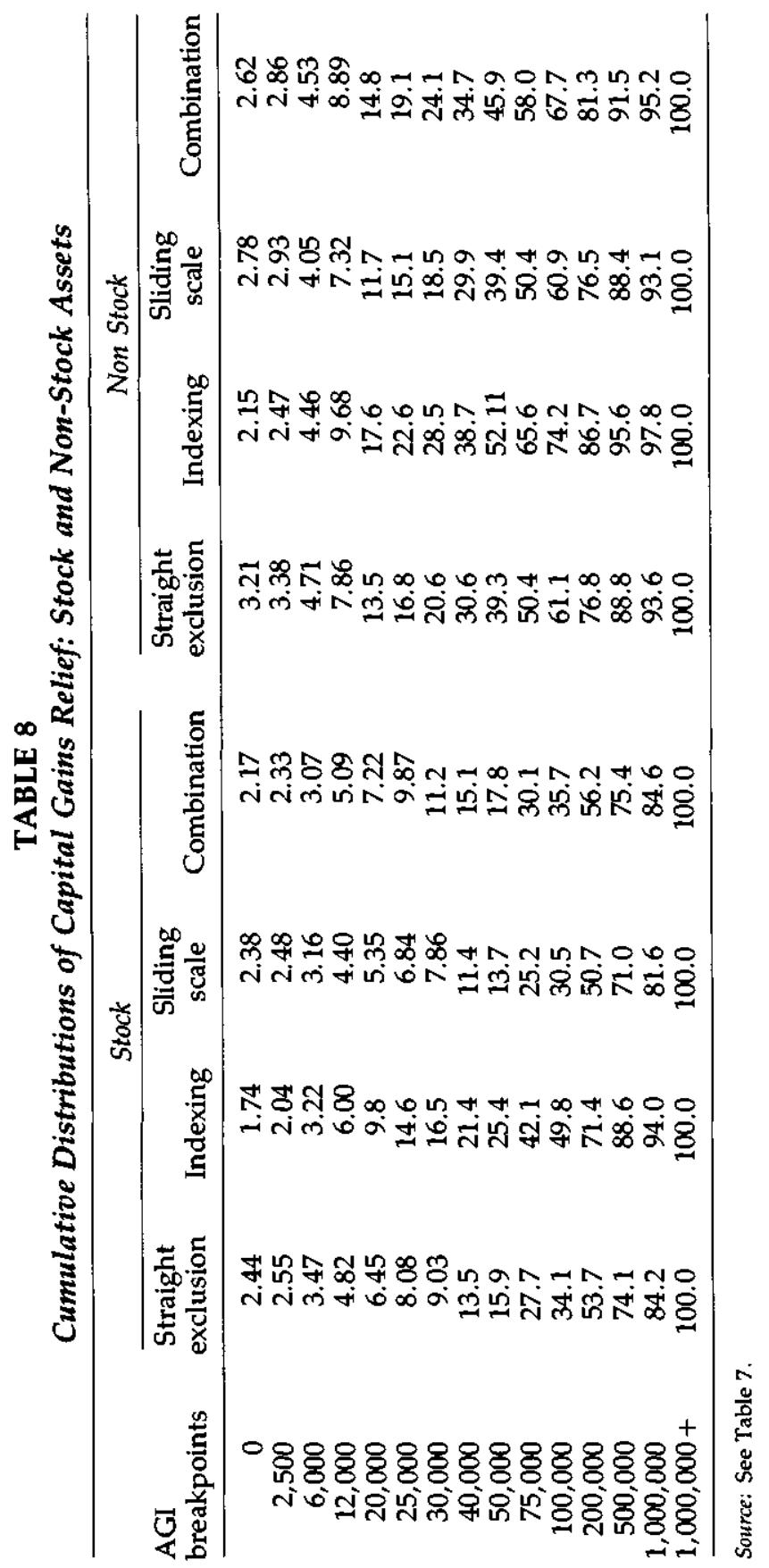


class. Second, for both corporate stocks and other assets, it appears that indexing is relatively more favorable to lower income taxpayers. This suggests that the differing distributional consequences of indexation and exclusion do not arise from differences in the types of asset held by high and low income taxpayers but instead are the result of differences in the realization behavior of high and low income taxpayers. ${ }^{3}$

The results in this section suggest that a conflict between the goals of promoting economic efficiency and equity in the design of capital gains tax reform proposals. While measures targeted to corporate stocks are more defensible on efficiency grounds than measures targeted at nonstock assets, their benefits are less evenly distributed. While indexation is more progressive a reform than a capital gains exclusion, its benefits are tilted toward the types of assets that are most easily leveraged, so its efficiency consequences are far from clear. Of course, efficiency issues matter only insofar as capital gains reforms affect new investment as opposed to assets that are already in place. The next section takes up this issue.

\section{CAPITAL GAINS TAX REFORM, NEW AND OLD INVESTMENT}

An important objective of capital gains tax reform is stimulating investment by reducing the cost of capital. Only reforms which affect new investment can have this effect. ${ }^{4}$ It is therefore interesting to gauge the share of the benefits of capital gains tax reductions that would apply to new as opposed to old capital. This depends on how long assets are held before being sold. If most realized capital gains occur on assets with long holding periods, then the share of the benefits of reform that go to new capital will be relatively low for the first few years after reform. The question of the length of the time that capital assets are held is also of interest because of concerns about the adverse consequences of "shorttermism" in business planning.

Table 9 presents information on the share of capital gains on assets that have been held for varying lengths of time. Three conclusions emerge. First, most capital gains taxes are paid on assets that have been

\footnotetext{
${ }^{3}$ It is conceivable that differential returns on stock between high and low bracket taxpayers arise in part because low bracket taxpayers are more likely to hold high dividend stocks that pay relatively small capital gains.

${ }^{4}$ Fairness issues certainly arise when considering tax plans which favor new over old capital. They may be less serious in the current context than in other ones because of the substantial difference between the tax rates at which most assets held today were depreciated, and the tax rate levied at present.
} 
TABLE 9

Cumulative Distributions of Benefits by Holding Period

\begin{tabular}{lcccc}
\hline $\begin{array}{l}\text { Held less } \\
\text { than }\end{array}$ & $\begin{array}{c}\text { Straight } \\
\text { exclusion }\end{array}$ & Indexing & $\begin{array}{c}\text { Sliding } \\
\text { scale }\end{array}$ & Combination \\
\hline 1 year & 0.0 & 0.0 & 0.0 & 0.0 \\
2 & 7.4 & 3.23 & 1.33 & 2.38 \\
3 & 14.2 & 8.59 & 3.73 & 6.51 \\
4 & 20.5 & 13.9 & 7.12 & 11.0 \\
5 & 26.9 & 18.8 & 11.6 & 20.0 \\
6 & 31.8 & 23.2 & 15.9 & 24.7 \\
7 & 37.1 & 26.8 & 21.6 & 29.6 \\
8 & 41.5 & 31.3 & 27.1 & 35.7 \\
9 & 47.0 & 36.7 & 33.9 & 39.9 \\
10 & 50.9 & 40.0 & 38.9 & 45.0 \\
15 & 70.6 & 60.9 & 63.3 & 63.2 \\
20 & 81.8 & 75.8 & 73.3 & 77.5 \\
Beyond & 100.0 & 100.0 & 100.0 & 100.0 \\
\hline
\end{tabular}

Source: See Table 7.

held for a fairly long time. The figures in the table imply that more than half of all capital gains taxes are paid on assets that have been held for 10 years or more. Only a very small fraction ( 7.4 percent) of capital gains taxes are paid on assets that have been held for less than one year, and only one-fifth of capital gains taxes are paid on assets that have been held for less than four years. This implies that there is only very limited scope to discourage short term trading by raising the tax rate on shortterm capital gains received by currently taxable investors. Indeed, the fact that reported short-term capital gains are typically negative suggests that such an approach might, by encouraging straddle-like strategies, actually increase the incidence of short term trading.

Second, a large fraction of the benefits of capital gains tax reductions would accrue to assets that were already in place at the time when a capital gains tax cut was enacted. For example, the table implies that even after five years, 75 percent of the benefits of an exclusion and 80 percent of the benefits of indexation would accrue to assets that were already in place when the reform was enacted. It is clear that virtually all of the benefits of a temporary capital gains tax cut would accrue to assets that had been purchased before the reform was enacted.

Third, there are modest differences between different reform plans in the extent to which long-term investments benefit. Because the sliding scale and the indexation options provide disproportionate relief to assets that have been held longer, their benefits are concentrated on holdings 
of long-term assets. Whereas half the benefits of a capital gains exclusion go to assets held more than 10 years, 60 percent of the benefits of indexing and 61 percent of the benefits of a sliding scale go to these assets. Perhaps the largest difference between the different plans is that the staggering and indexation options provide almost no relief to the small minority of assets that are sold in less than one year.

These estimates take no account of possible behavioral responses to a capital gains tax cut. To the extent that a capital gains tax cut stimulated realizations, they would be reinforced. The share of the benefit going to assets that had already been purchased increases if more of them were sold. Increasing the rate of realization necessarily implies reducing the horizon over which investors hold assets.

These estimates have a potentially important tax policy implication. They suggest that taxing only prospective capital gains would very significantly reduce the revenue cost of capital gains tax reform. In the short run, the revenue cost of indexing capital gains would be negligible as long as only prospective gains were to be indexed. Indeed, if taxpayers were required to realize gains on existing assets in order to qualify them for subsequent relief, prospective indexing might actually be a revenue raiser in the short run.

\section{CONCLUSIONS}

The analysis in this paper has reached three main conclusions by looking at the distribution of the benefits associated with capital gains tax reductions. First, using plausible measures of economic status, capital gains receipts are highly concentrated among those with high incomes. The richest 2 percent of Americans receive more than 50 percent of all capital gains. Claims that capital gains recipients only appear to be rich because their capital gains income is transitory are not supported by longitudinal data. Likewise, claims that a large fraction of the benefits from capital gains tax reductions flow to middle income taxpayers result from failing to consider tax shelters. Capital gains on corporate stocks are considerably more concentrated among high income individuals than capital gains on other assets.

Second, there are important differences in the distributional consequences of different approaches to reducing capital gains taxes. Indexation yields greater benefits to lower income taxpayers than a general capital gains exclusion because they typically hold assets longer before selling them, and because they typically enjoy smaller gains than higher income taxpayers. Indexation also favors real estate over corporate stocks to a much greater extent than does a general exclusion. A sliding 
scale capital gains tax cut, based on the amount of time an asset is held has distributional consequences very similar to a general exclusion.

Third, most capital gains are realized on assets that were held for 10 or more years. Reductions in capital gains taxes would, for many years, benefit primarily assets that are already in place. This is especially true of indexing and sliding scale plans. Confining capital gains tax relief to future gains would substantially reduce the revenue cost of capital gains reform.

The statistical work in the paper all assumes that there are no behavioral responses to changes in tax rates, an assumption which is surely unwarranted. However, it is unlikely that taking account of behavioral responses would alter the conclusions. Unless reductions in capital gains taxes would have a larger effect on realizations for lower than higher income taxpayers, taking account of behavioral effects would operate to strengthen the conclusion that capital gains tax reduction would primarily benefit high income taxpayers. Since they always have the option of not changing their realization strategy, any induced realizations following a tax cut are an indication that taxpayers are better off even if they do pay more in taxes. Conclusions about which assets would benefit most from capital gains tax reductions are probably not very sensitive to changes in behavior. And the conclusion that most of the benefits of capital gains cuts would go to assets that are already in place would be reinforced if behavioral effects were considered.

A broader argument challenging the results in this paper might assert that our assessment of the effects of capital gains cuts neglects the consequences of increased investment. Increased investment, it is argued would raise the productivity of labor and so raise wages, and by spurring capital accumulation would reduce pre-tax returns to capital. There is no question that such a general equilibrium effect of capital gains tax reductions would operate to make them more progressive. However, we are skeptical that this qualification is very important for our conclusions. First, as we have noted, most of the benefits of capital gains tax reductions go to old capital and so do not have incentive effects. Any favorable incentive effects on new capital are mitigated by the taxpayers' realization that the tax could be reformed yet again. Second, available estimates such as those of the Treasury's 1985 study suggest that reducing capital gains taxes would have only a negligible impact on long-term capital accumulation. To the extent that tax cuts would encourage real estate investments, it is questionable how much they would raise workers' productivity or wages. Third, capital gains tax reductions probably operate to increase the demand for capital but to reduce its supply. This is because they encourage individuals to sell capital assets, which may 
encourage them to spend the proceeds. To this extent, the impact of capital gains tax reductions on capital accumulation is ambiguous.

The analysis here highlights the conflicts inherent in designing a capital gains tax reform principle. The simplest reform, bringing back a partial capital gains exclusion benefits corporate stocks but is the most regressive of the reforms considered. Indexing on the other hand is progressive in its incidence but primarily benefits real estate and so may not increase the neutrality of the tax system. Indexing also favors old over new capital. The resolution of these conflicts as well as broader conflicts over the desirability of any type of capital gains tax reform will depend on the values policy makers attach to differing objectives as well as how they resolve judgments about the likely behavioral effect of tax changes.

\section{APPENDIX}

Three separate micro data files were used in the preparation of this study. All are public use samples of actual tax return data, as filed with the Internal Revenue Service.

The Individual Income Tax Model is a stratified random sample of individual income tax returns. High income returns are greatly oversampled (with sampling rates as high as one in three) and this enhances the usefulness of the file for a study of capital gains realizations. Weights are provided to reproduce the universe of taxpayers. The information included covers almost the complete Form 1040, but only a few items from each supporting schedule and only two-long and short net gains-from the Schedule D. No demographic data (such as age, race, or sex) are available, and even the age exemption is suppressed on returns with over $\$ 100,000$. It has 75,400 records.

The panel file used in Section I is a non-stratified random sample of individual income tax returns for the years 1979 through 1984. This is a longitudinal sample in which individual taxpayers appear repeatedly. Because high income returns are not oversampled, and the sample size is smaller, this file is not ideal for capital gains studies. Returns are included in the panel according to the last four digits of the primary taxpayer's social security number. In 1979-1981 five specific four-digit endings qualified a return for selection, yielding about 46,000 returns per year. In 1982 and 1984 budget stringency reduced the sample to a single four-digit ending and in 1983 to two such endings. Only one return per year was sampled, so a taxpayer filing late one year would not be included unless he or she continued to file late in subsequent years.

This unusual sampling scheme has a number of consequences. First, 
new taxpayers may enter the sample in any year. Second, taxpayers may enter and leave the sample at random according to the sampling rate each year or systematically according to their filing status. Third, women (who are rarely primary taxpayers on joint returns) leave the sample on marriage and reenter on divorce or widowhood.

For Table 2, six years of data are pooled. Out of 177,177 total returns, 92,146 belong to 15,384 taxpayers with four or more years of data available. Only these taxpayers are used. Because this selection process is non-random, the resulting tables are not directly comparable to the tax model files discussed above.

The 1973 Sales of Capital Assets file is the only file of individual transactions available for public use. It forms the basis for all our analysis of capital gains on different types of capital assets. The file contains about 415,000 (only 151,818 are usable) records of individual sales transactions as reported on Form 1040 Schedule D, Form 4797 and Form 2119 by 54,658 taxpayers with capital asset sales reported on calendar year 1973. For each transaction, the kind of property, purchase and sale dates, basis, selling price, and adjustments are given. In contrast to the other files used here, data are missing for a significant number of transactions. About 5 percent of transactions records lack purchase or sale price, and about 25 percent lack the purchase date. Suspiciously, the purchase date and month is always present if the purchase year is present. For transactions characterized as short-term gains by the taxpayer, we have assumed a six-month holding period if no purchase date was provided. 151,818 Schedule $D$ transactions for taxpayers with net gains are retained.

A separate file gives taxpayer information from the 1973 lndividual Income Tax Model, and this can be linked to the transaction data. This provides essentially the same information available in the lndividual Tax Model Files for later years, but only covers taxpayers with capital asset transactions. The 1986 Tax Model File (aged to 1989 levels) was used to generate average tax rates by AGl class for capital gains recipients.

ln all cases, dollar values are expressed in 1989 dollars. Aging of income flows to 1989 dollars was done using as a deflator, the change in per (adult) capita disposable income less transfers. In applying Fisher's law to the 1973 data to simulate recent inflation experience, we used the personal consumption deflator as a measure of inflation.

\section{REFERENCES}

Avery, Robert B. and Gregory E. Elliehausen. 1986. Financial Characteristics of High-Income Families. Federal Reserve Bulletin 72: 163-75. 
Congressional Budget Office. 1989. The Distribution of Benefits From a Reduction in the Tax Rate on Capital Gains. Staff Memorandum, October.

Gordon, Roger H., James R. Hines, Jr., and Lawrence H. Summers. 1987. Notes on the Tax Treatment of Structures. In The Effects of Taxation on Capital Accumulation, M. Feldstein, ed. Chicago: University of Chicago Press.

Internal Revenue Service. Undated. General Description Booklet for the 1986 Individual Public Use Tax File. Washington, D.C.

Poterba, James M. 1989. Venture Capital and Capital Gains Taxation. In Tax Policy and the Economy 3, L. Summers, ed. Cambridge: NBER and MIT Press.

Shoven, John B. 1989. The Japanese Tax Reform and the Effective Rate of Tax on Japanese Corporate Investments. In Tax Policy and the Economy 3, L. Summers, ed. Cambridge: NBER and MIT Press.

Slemrod, Joel, Laura Kalambokidis, and William Shobe. 1989. Who Realizes Capital Gains? Tax Notes, October 23.

Slemrod, Joel, 1988. The 1979-84 Linked Panel of Tax Return Data: Sampling and Linking Methodology. (unpublished memorandum, University of Michigan Business School).

Summers, Lawrence H. 1981. Inflation, the Stock Market, and Owner-Occupied Housing. American Economic Review 71: 429-34.

1987. Should Tax Reform Level the Playing Field? NTA-TIA Proceedings of the 79th Annual Conference, 119-24. Columbus, Ohio: NTA-TIA.

Yitzhaki, Shlomo. 1987. The Relation Between Return and Income. Quarterly Journal of Economics 102: 77-95. 